\title{
Epidural Ahesiolysis Provides Misinformation
}

\section{To The Editor:}

The manuscript by Hsu et al (1) published in Anesthesia \& Analgesia described factors associated with the treatment outcome of epidural lysis of adhesions. This analysis which they called the largest and the first of its nature, misses many important manuscripts and provides misinformation. It appears that authors may have misunderstood the epidural adhesiolysis procedure. The total number of patients included over a period of 4 years from 2 centers is rather small $(N=104)$, with an attempt to obtain too many variables. The outcomes at a glance show that only $50 \%$ of the patients reported a positive outcome in the short-term.

There have been multiple randomized, doubleblind, controlled trials performed in post surgery syndrome and spinal stenosis (2-7). Further, authors have based their entire description on an outdated, old, systematic review published in 2007 (8). Since then updated systematic reviews have been published in 2009 and $2012(9,10)$, as well as with updated guidelines $(11,12)$.

Authors also have described a procedure with a noncatheter technique and one with a catheter technique. Both procedures are incomplete and do not describe adhesiolysis.

Percutaneous adhesiolysis is indicated after the failure of caudal or interlaminar epidural injections. Caudal epidural injections have been well studied in post lumbar surgery syndrome with significant improvement in $59 \%$ with local anesthetic and $58 \%$ with steroids in well selected patients (13) and approximatey $50 \%$ of patients with central spinal stenosis with caudal (14) and over $80 \%$ with lumbar interlaminar $(15,16)$. Among the patients failing to respond to epidural injections, Manchikanti et al have illustrated significant improvement in post surgery syndrome and central spinal stenosis patients at the end of 2 years with repeat procedures as medically necessary, in $71 \%$ of patients with central stenosis (6) and $82 \%$ of patients with post surgery syndrome (4).

Laxmaiah Manchikanti, MD

Clinical Professor of Anesthesiology and

Perioperative Medicine

University of Louisville

Louisville, Kentucky

Medical Director

Pain Management Center of Paducah

2831 Lone Oak Road

Paducah, KY 42003

E-mail: drlm@thepainmd.com

Ramsin Benyamin, MD

Millennium Pain Center

1015 S. Mercer

Bloomington, IL 61701

E-mail: ramsinbenyamin@yahoo.com

Standiford Helm II, MD

The Helm Center for Pain Management Center

24902 Moulton Parkway

Suite 200

Laguna Hills, CA 92637

E-mail: drhelm@thehelmcenter.com

Joshua A. Hirsch, MD

Chief: Neurolnterventional Spine Service

Vice Chief: Interventional Care

Massachusetts General Hospital

Associate Professor of Radiology

Harvard Medical School

Boston, MA

E-mail: HIrsch@snisonline.org 


\section{References}

1. Hsu E, Atanelov L, Plunkett AR, Chai N, Chen Y, Cohen SP. Epidural lysis of adhesions for failed back surgery and spinal stenosis: Factors associated with treatment outcome. Anesth Analg 2014; 118:215-224.

2. Manchikanti L, Rivera JJ, Pampati V, Damron KS, McManus CD, Brandon DE, Wilson SR. One day lumbar epidural adhesiolysis and hypertonic saline neurolysis in treatment of chronic low back pain: A randomized, double-blind trial. Pain Physician 2004; 7:177-186.

3. Manchikanti L, Singh V, Cash KA, Pampati V, Datta S. A comparative effectiveness evaluation of percutaneous adhesiolysis and epidural steroid injections in managing lumbar post surgery syndrome: A randomized, equivalence controlled trial. Pain Physician 2009; 12:E355E368.

4. Manchikanti L, Singh V, Cash KA, Pampati V, Datta S. Assessment of effectiveness of percutaneous adhesiolysis and caudal epidural injections in managing lumbar post surgery syndrome: A 2-year follow-up of randomized, controlled trial. J Pain Res 2012; 5:597-608.

5. Manchikanti L, Cash KA, McManus CD, Pampati V, Singh V, Benyamin RM. The preliminary results of a comparative effectiveness evaluation of adhesiolysis and caudal epidural injections in managing chronic low back pain secondary to spinal stenosis: A randomized, equivalence controlled trial. Pain Physician 2009; 12:E341-E354.

6. Manchikanti L, Cash KA, McManus CD, Pampati V. Assessment of effectiveness of percutaneous adhesiolysis in managing chronic low back pain secondary to lumbar central spinal canal stenosis. Int J Med Sci 2013; 10:50-59.
7. Gerdesmeyer L, Wagenpfeil S, Birkenmaier $C$, Veihelmann A, Hauschild $M$, Wagner K, Al Muderis M, Gollwitzer H, Diehl P, Toepfer A. Percutaneous epidural lysis of adhesions in chronic lumbar radicular pain: A randomized double-blind placebo controlled trial. Pain Physician 2013; 16:185-196.

8. Trescot AM, Chopra P, Abdi S, Datta S Schultz DM. Systematic review of effectiveness and complications of adhesiolysis in the management of chronic spinal pain: an update. Pain Physician 2007; 10:129-146.

9. Epter RS, Helm S, Hayek SM, Benyamin RM, Smith HS, Abdi S. Systematic review of percutaneous adhesiolysis and management of chronic low back pain in post lumbar surgery syndrome. Pain Physician 2009; 12:361-378.

10. Helm II S, Benyamin RM, Chopra P, Deer TR, Justiz R. Percutaneous adhesiolysis in the management of chronic low back pain in post lumbar surgery syndrome and spinal stenosis: A systematic review. Pain Physician 2012; 15:E435-E462.

11. Manchikanti L, Boswell MV, Singh V, Benyamin RM, Fellows B, Abdi S, Buenaventura RM, Conn A, Datta S, Derby R, Falco FJE, Erhart S, Diwan S, Hayek SM, Helm S, Parr AT, Schultz DM, Smith HS, Wolfer LR, Hirsch JA. Comprehensive evidence-based guidelines for interventional techniques in the management of chronic spinal pain. Pain Physician 2009; 12:699-802.

12. Manchikanti L, Abdi S, Atluri S, Benyamin RM, Boswell MV, Buenaventura RM, Bryce DA, Burks PA, Caraway DL, Calodney AK, Cash KA, Christo PJ, Cohen SP, Colson J, Conn A, Cordner HJ,
Coubarous S, Datta S, Deer TR, Diwan SA, Falco FJE, Fellows B, Geffert SC, Grider JS, Gupta S, Hameed H, Hameed $M$, Hansen H, Helm II S, Janata JW, Justiz R, Kaye AD, Lee M, Manchikanti KN, McManus CD, Onyewu O, Parr AT, Patel VB, Racz GB, Sehgal N, Sharma $M$, Simopoulos TT, Singh V, Smith HS, Snook LT, Swicegood J, Vallejo R, Ward SP, Wargo BW, Zhu J, Hirsch JA. An update of comprehensive evidence-based guidelines for interventional techniques of chronic spinal pain: Part II: Guidance and recommendations. Pain Physician 2013; 16:S49-S283.

13. Manchikanti L, Singh V, Cash KA, Pampati V, Datta S. Fluoroscopic caudal epidural injections in managing post lumbar surgery syndrome: Two-year results of a randomized, double-blind, activecontrol trial. Int J Med Sci 2012; 9:582591.

14. Manchikanti L, Cash KA, McManus CD, Pampati V, Fellows B. Results of 2-year follow-up of a randomized, doubleblind, controlled trial of fluoroscopic caudal epidural injections in central spinal stenosis. Pain Physician 2012; 15:371384 .

15. Manchikanti L, Cash KA, McManus CD, Damron KS, Pampati V, Falco FJE. Lumbar interlaminar epidural injections in central spinal stenosis: Preliminary results of a randomized, double-blind, active control trial. Pain Physician 2012; 15:51-63.

16. Manchikanti L, Cash KA, McManus CD, Damron KS, Pampati V, Falco FJE. A randomized, double-blind controlled trial of lumbar interlaminar epidural injections in central spinal stenosis: 2-year follow-up. Pain Physician 2015; 18:79-92. 